\title{
Pola Pengasuhan Anak pada Orang Tua Tuna Netra (Studi Kasus Klinik Pijat Tuna Netra Barokah)
}

\author{
Rani Kartika \\ rani.kartika@gmail.com \\ Universitas Negeri Padang
}

\author{
Disubmit \\ 11 Mei 2018
}

Direvisi

3 Desember 2018

http://dx.doi.org/10.17509/jpis.v27i2.14095
Diterima

30 Desember 2018

\begin{abstract}
Persons with disabilities are part of a multicultural society. Therefore, there is a need for interrelated awareness from the community that does not look at one eye. This research uses qualitative with a case study method. Data collection techniques used in this study were observation, interviews and documentation studies. Parenting blind people in this study used evolutionary and authoritarian parenting. While challenging parents with visual impairments in terms of normal parenting is that parents can be blind parents to help with learning difficulties in school because of the difficulty of their eyesight. The first abstract is written in English. Abstract length maximum 250 words. At least the abstract should include the objectives of the study, research subjects, research methods, research results and recommendations. The abstract should include two to five keywords. The format of writing follows the template.
\end{abstract}

Keywords: Parenting Parents, Blind / Disabled, Normal Children.

\begin{abstract}
ABSTRAK
Penyandang disabilitas merupakan salah satu bagian dari masyarakat multikultural. Maka dari itu perlu adanya kesadaran saling menghargai dari masyarakat tidak memandang sebelah mata kaum penyandang disabilitas terutama dalam hal pengasuhan anaknya yang terlahir normal. Penelitian ini menggunakan pendekatan kualitatif dengan metode studi kasus. Teknik pengumpulan data yang digunakan dalam penelitian ini adalah observasi, wawancara dan studi dokumentasi. Hasil penelitian menunjukkan bahwa penerapan pola asuh orang tua tunanetra dalam penelitian ini menggunakan pola asuh demokratis dan otoriter. Adapun kendala-kendala orang tua tunanetra dalam hal mengasuh anaknya yang normal adalah tidak mampunya orang tua tunanetra membantu anaknya yang mengalami kesulitan belajar di sekolah karena keterbatasan penglihatannya.
\end{abstract}

Kata Kunci: Pola Asuh Orang Tua, Tunanetra/Disabilitas, Anak Normal.

\section{PENDAHULUAN}

Secara umum masyarakat multikultural di Indonesia ditandai dengan adanya keanekaragaman suku, ras, agama, adat istiadat, bahasa. Namun, keberagaman masyarakat multikultural tidak hanya dipandang dalam segi tersebut. Ada indikator lain yang juga masuk ke dalam masyarakat multikultural yaitu bahwasannya disabilititas merupakan salah satu termasuk ke dalam bagian dari masyarakat multikultural. Hal ini sering 
diabaikan orang sebagian masyarakat yang berpandangan bahwa disabilitas dianggap mempunyai kelemahan dan keterbatasan dalam segi fisik dibandingkan dengan orang yang normal pada umumnya.

Menurut data dari Kementerian Sosial RI, pada tahun 2011, jumlah penyandang disabilitas di Indonesia mencapai 3,11\% atau sebesar 6,7 juta jiwa. Sedangkan menurut Kementrian kesehatan RI, jumlah penyandang disabilitas lebih besar yaitu $6 \%$ dari total populasi penduduk Indonesia. Apabila mengacu pada standar Organisasi Kesehatan Dunia (WHO) yang lebih ketat, jumlah penyandang disabilitas di negara berkembang sebesar 10\% dari total populasi penduduk. Berdasarkan survei dari PT Surveyor Indonesia (Persero), jumlah populasi penyandang disabilitas tertinggi berada di Provinsi Jawa Barat yaitu sekitar 50,90\%. Sedangkan populasi terendah berada di Provinsi Gorontalo yaitu sekitar 1,65\%. Pada tahun 2012, jumlah penyandang disabilitas di Indonesia tercatat yaitu Tunanetra $\quad 1.749 .981 \quad$ jiwa, Tunarungu/wicara 602.784, Tunadaksa 1.652. 741 jiwa dan Tunagrahita 777.761 jiwa.

Dengan melihat kenyataan seperti ini, maka dapat dikatakan penyandang Tunanetra di Indonesia cukup banyak bila dibandingkan dengan penyandang disabilitas yang lain. Melihat fakta ini bisa saja kemungkinan segelintir kecil keluarga memiliki sanak saudara yang menyandang tunanetra, bahkan tidak menutup kemungkinan seorang penyandang tunanetra membangun kehidupan berumah rumah tangga dan mempunyai anak (Rusch, 1990). Tidak menutup kemungkinan pula bahwa anak yang dilahirkan dari pasangan tunanetra itu normal atau kemungkinan juga terlahir sebagai penyandang tunanetra.

Orang tua yang menyandang tunanetra tentu saja mempunyai suatu pola atau pun cara tertentu dalam mendidik dan mengasuh anak-anak mereka. Meskipun mereka tidak terlahir dengan kondisi normal seperti manusia lainnya. Namun orang tua tunanetra tetap akan berusaha membina keluarga dan anaknya agar menjadi pribadi yang baik dan membanggakan orang tua. Berbeda dengan orang tua yang sehat dan bugar secara jasmani dapat mendampingi, mengawasi dan membimbing anak dalam melakukan kegiatan seperti belajar atau bermain, juga dapat membantu mengatasi kesulitan yang dihadapi anak dalam melakukan suatu kegiatan.

Pada akhri-akhir ini kenakalan remaja sungguh dalam kondisi yang memperhatinkan. Keadaan ini tidak hanya terjadi di kota metropolitan tetapi juga sudah merambah ke daerah dan kota-kota kecil. Kenakalan remaja dimulai dari perilaku menyimpang sampai dengan tindak pidana kekerasan. Perilaku kekerasan pada remaja merupakan fenomena yang akhir-akhir ini sering mengganggu ketentraman masyarakat. Kenakalan remaja dapat ditimbulkan oleh beberapa hal, sebagian diantaranya adalah pengaruh teman sebaya, penggunaan waktu luang, uang saku, perilaku seksual, serta pengasuhan orang tua terhadap anaknya.

Pengasuhan dan pendidikan orang tua terhadap anaknya merupakan faktor utama terhadap terbentuknya perilaku anak. Orang tua yang kurang mampu melakukan pengasuhan intensif akan berpotensi terhadap kurang optimalnya pertumbuhan dan perkembangan kematangan perilaku anak. Apabila pengasuhan yang 
dilakukan oleh orang tua dianggap sebagai cara yang umum untuk mengelola keluarga, maka hal itu akan menjadi warisan budaya. (Darling \& Steinberg, 1993) mengemukakan bahwa anak yang diasuh dengan gaya permisif cenderung tidak dewasa, sulit mengontrol diri dan bertindak bebas, sedangkan anak yang diasuh orang tua otoriter didapatkan cemas dan menarik diri, kurang spontan dan cerdas. Diduga saat dewasa kurang harmonis dan lebih banyak konflik. Sedangkan pengasuhan orang tua dengan cara demokratis akan membuat anak lebih terbuka kepada orang tuanya terhadap permasalahan yang sedang dihadapi anak.

Saat ini orang tua harus berpikir lebih jauh tentang bagaimana membesarkan dan mengasuh anaknya. Hal ini dikarenakan kondisi masyarakat sudah sangat jauh berbeda dari jaman ke jaman. Adanya globalisasi, teknologi tinggi, arus informasi dan budaya transfaransi membutuhkan orang tua yang tidak hanya baik dengan nilai yang dianutnya tetapi juga cerdas dalam berinteraksi dengan anak. Orang tua yang dibutuhkan oleh anak adalah yang cukup memiliki ikatan emosional yang baik tetapi tidak lupa untuk menegakkan disiplin dan memahamkan anak tentang norma kehidupan. Orang tua yang memiliki cukup waktu dan interaksi yang intensif pada saat bersama-sama anak (Carr \& Alan, 2009).

Setiap orang tua pasti memiliki harapan agar anak-anaknya menjadi anak yang pandai, cerdas, berakhlak dan berguna bagi semua orang. Akan tetapi dalam kenyataannya, tidak semua manusia terlahir ke dunia ini sebagai manusia yang normal. Ada manusia yang pada sejak lahir mengalami kecacatan atau pada saat pertumbuhan mengalami kecacatan ataupun ketunaan secara fisik. Hal ini menjadi masalah bagi manusia yang mengalami keterbatasan fisik atau dikenal dengan istilah penyandang difabel. Difabel adalah suatu istilah atau sebutan yang pada dewasa ini sudah mulai digunakan untuk mengganti kata penyandang cacat. Difabel sendiri didefinisikan sebagai orang yang mengalami keterbatasan fisik. Dengan kata lain para penyandang difabel bukan dipandang sebagai orang yang menyandang cacat, akan tetapi penyandang difabel pada saat ini lebih dipandang sebagai orang-orang yang memiliki kemampuan yang berbeda dengan orang lainnya. Dalam hal ini, maka pentingnya bagi kita untuk saling menghargai dan mengormati penyandang difabel dengan keterbatasannya mampu membina keluarganya yang sejahtera.

Oleh sebab itu peneliti tertarik untuk meneliti dengan keterbatasannya, bagaimana pasangan suami istri tunanetra menerapkan pola asuh terhadap anak yang terlahir normal.

\section{RUMUSAN MASALAH}

Berdasarkan uraian fenomena latar belakang diatas, maka dapat dirumuskan beberapa permasalahan yang menjadi fokus untuk penelitian. Rumusan tersebut kemudian diuraikan kedalam tiga pertanyaan penelitian yakni:

1) Bagaimana pola asuh orang tua tunanetra terhadap anak yang normal?

2) Apa saja kendala-kendala orang tua tunanetra dalam mengasuh anaknya yang normal?

3) Bagaimana upaya yang dilakukan orang tua tunanetra dalam mengatasi kendala dan 
keterbatasannya mengasuh anak yang normal?

\section{TUJUAN PENELITIAN}

Berdasarkan rumusan masalah diatas, maka tujuan yang ingin dicapai dalam penelitian ini adalah:

1) Untuk menjelaskan kecenderungan pola asuh orang tua tunanetra terhadap anaknya yang terlahir normal.

2) Untuk menjelaskan kendala-kendala orang tua tunanetra dalam mengasuh anaknya yang normal.

3) Untuk menjelaskan upaya yang dilakukan orang tua tunanetra dalam mengatasi kendala dan keterbatasannya mengasuh anak yang normal.

\section{KAIIAN LITERATUR \\ Disabilitas Multikultural}

Disabilitas adalah sebuah konsep yang menjelaskan hasil dari interaksi antara individu-individu yang mempunyai keterbatasan fisik atau mental/intelektual dengan sikap dan lingkungan yang menjadi penghambat kemampuan mereka berpartisipasi di masyarakat secara penuh dan sama dengan orang-orang lainnya. Pengakuan ini secara tidak langsung menyatakan bahwa persoalan hambatan berpartisipasi harus menjadi tanggung jawab masyarakat dan Negara juga.

Sikap masyarakat dan kebijakan pemerintah yang mengakomodasi prinsip HAM non-diskriminasi, kesetaraan serta kesempatan yang sama dan mengakui adanya keterbatasan yang dapat diatasi jika diupayakan aksesibilitas fisik dan nonfisik merupakan faktor penting dalam mengatasi kondisi (Meyer, 2001) yang disebut "disabilitas". Peningkatan kesadaran masyarakat dan tanggung jawab Negara untuk mengatasi disabilitas menjadi tugas penting dari komunitas bangsa-bangsa di dunia sehingga setiap orang, terlepas dari jenis dan keparahan kecacatan (impairment) yang dimiliki mampu menikmati hak-hak mereka yang paling hakiki.

\section{Pola Pengasuhan Orang Tua}

Ada tiga jenis pola asuh orang tua, yaitu sebagai berikut:

Authoritative Parenting (Pola asuh demokrasi)

Pola asuh orang tua dengan demoktaris membantu anak untuk belajar tanggung jawab bagi mereka sendiri dan berpikir tentang konsekuensi atas perilaku mereka sendiri. orang tua melakukan hal ini dengan jelas, harapan yang bisa dijelaskan bagi anaknya dan menjelaskan mengapa mengharapkan anaknya untuk melakukan sikap tertentu. Mereka mengawasi perilaku anak mereka untuk meyakinkan bahwa mereka mengikuti aturan dan harapan. Mereka melakukan ini dalam sikap kehangatan cinta (Lannelli Vincent, 2004).

Upaya orang tua demoktaris untuk mengarahkan kegiatan anak tetap dalam rasionalitas, isu berorientasi pada cara. Orang tua lebih memberi secara verbal dan menerima. Otonomi anak akan diri dan disiplin sangat diharapkan. Orang tua memaksa perspektif sendiri sebagai orang dewasa, tetapi mengakui kepentingan individu dan anak dengan cara khusus. Orang tua otoritatif hadir tidak hanya menegaskan kualitas anak, 
tetapi juga menetapkan standar untuk melakukan masa depan. Dia menggunakan alasan, kekuatan, dan membentuk aturan dan penguatan untuk mencapai tujuannya, dan tidak mendasarkan keputusan di atas komponen kelomok atau individu kepentingan anak (Baumrind, 1966).

Authoritarian Parenting (Pola asuh otoriter)

Pola asuh otoriter memberi sedikit keterangan atau bahkan tidak memberikan keterangan pada anak tentang alasan-alasan mana yang dapat dilakukan dan mana yang tidak boleh dilakukan, mengabaikan alasan-alasan yang masuk akal dan anak tidak diberikan kesempatan menjelaskannya, hukuman diberikan orangtua kepada anak yang melakukan kesalahan, hadiah atau penghargaan (reward) jarang diberikan kepada anak yang telah melakukan perbuatan baik atau telah menunjukan prestasinya. Orang tua jenis ini tidak mengenal kompromi dan dalam komunikasi biasanya bersifat satu arah. Orang tua jenis ini tidak memerlukan umpan balik dari anaknya untuk mengerti mengenai anaknya.

Orang tua yang otoriter selalu mencoba mengendalikan dan memaksakan pengendalian itu pada anak mereka. Orang tua menyusun aturan kaku untuk mencoba menjaga pelaksanaan tugas-tugas yang dibebankan pada anak, dan mereka umumnya melakukan ini tanpa banyak ekspresi kehangatan dan perasaan (Baumrind, 1966). Mereka mencoba menyusun standar kaku dalam kepemimpinan dan umumnya sangat kritis pada anak jika tidak sesuai dengan standar orang tua. Mereka mencoba anknya patuh dan tidak menyediakan anak dengan pilihan atau alternatif.

Permissive Parenting Style (pola asuh permisif)

Pola asuh permisif membuat beberapa peraturan dan mengijinkan anak-anaknya untuk memonitor kegiatan mereka sebanyak mungkin. Ketika mereka membuat peraturan biasanya mereka menjelaskannya terlebih dahulu, orang tua berdiskusi dahulu dengan anak dan orang tua tidak mau menghukum anak jika melakukan pelanggaran. Orang tua membuat beberapa atau sedikit aturan yang mereka buat sering tidak konsisten ditegakan. Mereka tidak ingin terikat pada rutinitas. Dia ingin anaknya merasakan kebebasan. Mereka tidak menyusun batasan yang jelas atau harapan terhadap perilaku anak mereka dan cenderung menerima dalam kehangatan dan cinta walaupun kelakuan anak negatif (Lannelli Vincent, 2004). Mereka cenderung menerima perilaku anak baik atau buruk dan tidak banyak mengomentari apakah itu menguntungkan atau tidak.

\section{Teori Pola Pengasuhan Anak}

Salah satu teori yang melandasi studi keluarga diantaranya adalah Teori Struktural fungsional/Teori Sistem. Talcott Parsons (Ritzer \& Goodman, 2010) terkenal dengan konsep pendekatan sistem melalui AGIL (Adaptation; Goal Attainment; Integration; and Latency), yaitu adaptasi dengan lingkungan, adanya 
tujuan yang ingin dicapai, integrasi antar sub-sub sistem, dan pemeliharaan budaya atau norma/nilai-nilai/kebiasaan.

1) Adaptasi, sebuah sistem ibarat makhluk hidup, artinya agar dapat terus berlangsung hidup, sistem harus dapat menyesuaikan diri dengan lingkungan yang ada.

2) Goal (pencapaian), sebuah sistem harus memiliki suatu arah yang jelas dapat berusaha mencapai tujuan utamanya.

3) Integrasi, sebuah sistem harus mengatur hubungan antar bagian yang menjadi komponennya.

4) Latensi, (pemeliharaan pola), sebuah sistem harus melengkapi, memelihara dan memperbaiki polapola kultural yang menciptakan dan menopang motivasi.

Pendekatan struktural-fungsional menekankan pada keseimbangan sistem yang stabil dalam keluarga dan kestabilan sistem sosial dalam masyarakat. Pendekatan teori struktural-fungsional dapat digunakan dalam menganalisis peran keluarga agar dapat berfungsi dengan baik untuk menjaga keutuhan keluarga dan masyarakat. Keluarga adalah unit universal yang memiliki peraturan, seperti peraturan untuk anak-anak agar dapat belajar untuk mandiri. Tanpa aturan atau fungsi yang dijalankan oleh unit keluarga, maka unit keluarga tersebut tidak memiliki arti (meaning) yang dapat menghasilkan suatu kebahagiaan. Bahkan dengan tidak adanya peraturan maka akan tumbuh atau terbentuk suatu generasi penerus yang tidak mempunyai daya kreasi yang lebih baik dan akan mempunyai masalah emosional serta hidup tanpa arah.

\section{METODE PENELITIAN}

Dalam penelitian ini, peneliti menggunakan pendekatan kualitatif dengan metode studi kasus. Peneliti berusaha memahami pola asuh tunanetra terhadap anak yang terlahir normal melalui kajian secara mendalam yang terfokus pada suatu kasus tertentu untuk diamati dan dan dianalisis secara cermat sampai tuntas. Kasus yang dimaksud bisa berupa individu atau kelompok dengan memusatkan perhatian pada suatu kasus secara intensif dan rinci. Subjek penelitian ini memusatkan pada pola asuh orang tunanetra terhadap anak yang terlahir normal. Lokasi penelitian ini dilakukan di Klinik Pijat Tunanetra Barokah Jalan Setia Budhi Bandung yang kliniknya membuka pelayanan pijat mulai dari jam 08.00 hingga jam 20.00. Pemilihan lokasi ini dikarenakan klinik ini baru dibuka dalam beberapa bulan ini dan di sana terdapat 2 pasangan suami istri tunanetra yang bekerja.

Dengan mereka bekerja selama 12 jam tentunya pengasuhan kepada anaknya tidaklah seoptimal mungkin. Hal ini tentu membuat kurangnya waktu untuk bersama dengan anak dan keluarga, yang kemudian berpengaruh juga terhadap kualitas dan jenis pola asuh yang diberikan. Teknik pengumpulan data yang digunakan dalam penelitian ini meliputi wawancara mendalam, observasi dan studi dokumentasi. Adapun teknik analisis data yang digunakan melalui tiga tahap yaitu reduksi data, penyajian data dan penarikan kesimpulan. Sedangkan untuk menguji keabsahan data pada penelitian ini digunakan teknik triangulasi data. 


\section{HASIL DAN PEMBAHASAN}

Selama berada di lapangan, didapatkan data bahwa pasangan suami istri tunanetra yang mempunyai anak dan bekerja di Klinik Barokah terdapat 2 keluarga yaitu keluarga pak Cecep (39 tahun) dan bu Arin (35 tahun), dan keluarga pak Maman (50 tahun) dengan bu Devi (45 tahun). Orang tua tunanetra dari dua keluarga yang menjadi subjek penelitian ini selain berperan sebagai pemijat di Klinik Pijat Tunanetra Barokah, juga berperan sebagai orang tua yang berupaya menerapkan pola asuh sesuai dengan kemampuannya.

Berdasarkan wawancara dan observasi dengan tunanetra yang bernama Arin, umur 35 tahun berasal dari Medan yang bekerja baru selama 2 bulan di Klinik Pijat Tunanetra Barokah yang dahulunya selama 14 tahun setelah tamat SMA ia bekerja di Klinik Pijat Rotary Medan yang memperkerjakan 33 pemijat tunantera. Namun kini klinik tersebut telah tutup karena pemiliknya sudah pindah ke Taiwan, sehingga banyak dari para pekerja tunantera di sana yang pindah ke luar kota mencari pekerjaan. Begitu juga dengan bu Arin ini yang mendapatkan suami (pak Cecep, umur 39 tahun yang juga tunanetra) selama ia bekerja di klinik Rotary tersebut dan mencoba merantau ke Bandung untuk mencari pekerjaan sebagai tukang pijat. Bu Arin dan pak Cecep memiliki 2 orang anak laki-laki yang normal dan sekarang berada di kelas 6 SD dan kelas 3 SD.

Kehadiran seorang anak bagi Pak Cecep dan Ibu Arin merupakan dambaan setiap orang tua. Saat mereka diberitahu oleh dokter bahwa kelahiran anak pertama dan kedua terlahir normal dari segi fisik dan mempunyai anggota badan yang lengkap, mereka merasa bahagia dan senang sekali.
Sebagai seorang ibu tentunya menyiapkan diri secara mental dan fisik terlebih pada kehamilan anak pertama. Berbagai persiapan kebutuhan alat-alat bayi seperti sabun, ember, pakaian bayi dan sebagainya. Pada waktu kelahiran anaknya, Pak Cecep dan Bu Arin juga melakukan syukuran dengan mengundang tetangga-tetangga dekat rumahnya.

Saat ini kedua anaknya mereka titipkan dengan orang tuanya di Medan karena ia baru mencoba merantau ke Bandung dalam beberapa bulan ini dan mengingat biaya sekolah anak jika dipindahkan ke Bandung biayanya sangatlah besar dan semuanya itu harus dimulai dari nol. Anaknya bersekolah di yayasan swasta yang cukup terbagus di kota Medan. Bu Arin dan pak Cecep mengatakan bahwa walaupun dengan keterbatasan kondisi matanya yang tidak bisa melihat, namun untuk pendidikan anaknya ia tidak mau kalah dengan anak-anak yang berasal dari orang tua yang normal.

Dalam hal pengasuhan anak, pak Cecep dan Ibu Arin dibantu oleh orang tuanya kerena mereka setelah menikah tidak diperbolehkan oleh orang tua $\mathrm{Bu}$ Arin untuk mengontrak rumah. Selama $\mathrm{Bu}$ Arin dan Pak Cecep mengasuh anaknya di Medan dengan bersikap tegas bahkan keras ketika menghadapi hal-hal seperti dalam aspek pendidikan anak, pergaulan anak dan penyimpangan atau pelanggaran yang dilakukan oleh anak. Karena kedua anaknya laki-laki, mereka takut terjadi sesuatu yang tidak diinginkan apalagi sekarang sudah maraknya kasus narkoba, jika tidak tegas nantinya akan mudah dibohongi oleh anaknya sendiri.

Jika anaknya berbohong misalnya tidak mengerjakan tugas yang diberikan oleh guru di sekolah, maka bu Arin memberikan peringatan satu atau 
dua kali dengan bahasa yang lemah lembut dan mengarahkan anak ke hal yang baik. Akan tetapi ketika terusmenerus terjadi baru bu Arin memberikan ketegasan dengan bahasa yang lebih keras kepada anaknya dan memberikan sanksi kepada anaknya ketika ia berbohong seperti di kurung di kamar mandi dan tidak diberikan uang jajan. Hal ini dilakukan agar anak tidak menjadi pribadi yang manja sehingga tidak dapat mandiri kedepannya.

Namun, dalam hal pendidikan untuk anaknya mereka selalu memprioritaskan seperti memberikan fasilitas guru privat bagi anak-anaknya yang mengalami kesulitan belajar karena keterbatasannya dalam hal penglihatan yang tidak mampu mengajarkan kesulitan belajar yang dihadapi anak sepenuhnya dan juga mengingat penuhnya waktu mereka bekerja di klinik pijat tersebut. Akan tetapi mereka selalu berusaha untuk berkonsultasi dengan guru di sekolah dan guru privatnya ketika anaknya mengalami kesulitan dalam belajar. Karena bagi mereka, pendidikan untuk anak-anaknya sangatlah menjadi hal yang paling utama agar kelak masa depan anaknya lebih baik dari orang tuanya.

Menurutnya bekerja sebagai tukang pijat bagi merupakan pekerjaan bergengsi daripada mengemis belas kasihan dengan meminta-minta. Karena untuk pandai memijat ini banyak proses yang ia lakukan mulai dari setelah lulus SMA lalu masuk ke pelatihan-pelatihan pijat hingga mendapatkan tes lulus/sertifikat dari kedokteran mengenai anatomi tubuh manusia dalam memijat. Menurutnya bahwa di klinik pijat tunanetra Rotary yang milik Cina di Medan tersebut merupakan klinik pijat tunanetra yang bukan sembarangan orang yang bisa masuk disana. Karena klinik pijat Rotary tersebut memberikan surplus yang besar kepada tunanetra mulai dari jaminan kesehatan, jaminan pendidikan anak hingga tunjangan-tunjangan bagi tunanetra yang bekerja secara profesional. Namun karena perusahaan klinik pijat ini sudah tutup, maka mereka memutuskan untuk merantau ke Bandung. Berbeda klinik pijat Barokah ditempat mereka bekerja sekarang yang baru dibuka dalam beberapa bulan ini yang masih merintis demi mensejahterakan tunanetra.

Dalam pencapaian kebutuhan ekonomi keluarga, mereka mengatakan selama ia bekerja memijat di klinik Rotary tersebut semua ketubuhan rumah tangganya sudah lebih dari cukup. Karena setiap bulannya ia mendapatkan gaji yang lumayan besar yaitu berkisar Rp3-5 juta. Dari gaji yang lumayan besar tersebut mereka sisihkan untuk tabungan di hari tua dan masa depan anak-anaknya. Namun, bekerja di klinik Barokah ini mereka mengatakan karena klinik ini baru dibuka beberapa bulan ini, gaji mereka berkisar Rp1,5-2 juta per bulannya yang cukup untuk memenuhi kebutuhan hidup sehari-hari dalam hal membayar kontrakan rumah, membayar tagihan listrik, dan kebutuhan makan seharihari.

Kendala-kendala yang mereka temui dalam mencapai kebutuhan ekonomi rumah tangga selama memijat di kinik Barokah ini hanya karena cukup memenuhi kebutuhan sehari-hari tidak bisa untuk menabung. Jika uang bulanan mereka tidak mampu mencukupi kebutuhan sehari-harinya ditambah lagi dengan pengiriman biaya anaknya yang bersekolah di Medan, maka upaya yang mereka lakukan adalah meminjam uang kepada pemilik/atasan klinik Barokah ini, dan 
kadang-kadang untuk mengantisipasi kekurangan kebutuhan ekonomi rumah tangga, ia mengambil uang yang ada di tabungannya.

Wawancara selanjutnya dengan tunanetra pasangan suami istri yaitu ibu Devi yang berusia 45 tahun, asal Tasikmalaya dan Bapak Maman asal Tasikmalaya, umur 50 tahun yang sudah bekerja memijat selama 17 tahun setelah lulus SMA. Mereka mempunyai 2 orang anak normal yang anak pertamanya adalah laki-laki kelas 2 SMA yang bekerja membantu dalam hal administrasi di klinik pijat ini. Dan 1 orang lagi anaknya adalah perempuan kelas 1 SD yang kini bersekolah di Tasikmalaya. Kehadiran anak bagi pak Maman dan bu Devi merupakan sesuatu yang sangat ditunggu-tunggu karena anak itu adalah rejeki, tentu saja merasa bahagia sebab Tuhan masih mempercayainya untuk mendidik anak.

Ibu Devi dan bapak Maman awalnya belajar memijat dengan ikut pelatihanpelatihan pijat dari Binaan Dinas Sosial Tasikmalaya. Setelah mengikut pelatihan-pelatihan dan mahir dalam memijat, mereka membuka pijat di rumahnya saja. Namun karena semakin mahalnya biaya hidup rumah tangga dan biaya sekolah anaknya, ia memutuskan untuk merantau ke Bandung yang kebetulan di klinik pijat Barokah dikhususkan untuk tunanetra. Mereka tingal di Bandung ini sudah 2 tahun dan mengontrak rumah di belakang klinik pijat ini.

Ibu Devi dan Bapak Maman yang dikenal ramah oleh pelanggannya dalam memijat dan sudah lama tinggal di Bandung tentunya banyak mendapatkan pelanggan dibandingkan dengan keluarga pak Cecep dan ibu Arin yang baru merantau ke Bandung. Baginya, bahwa dengan keahliannya dalam memijat membuat dirinya terpandang dibandingkan dengan meminta-minta belas asihan kepada orang lain seperti menjadi pengemis. Karena orang tuanya selalu memotivasinya untuk terus berkarya sewaktu ia mengalami cacat mata sejak lahir. Menurutnya hanya mata saja yang tidak bisa melihat, anggota tubuh lainnya masih mampu mereka gunakan dalam mencari nafkah.

Dalam memenuhi kebutuhan ekonomi keluarga menurut mereka dengan bekerja sebagai memijat sudah lebih dari cukup. Hal ini tergantung dari bagaimana kita mampu mengatur pemasukan dan pengeluaran dari hasil kerja. Pendapatan pak Maman dan Ibu Devi ini dalam memijat lumayan besar yaitu berkisar Rp2-3 juta per bulannya karena mereka sudah banyak mendapatkan pelanggan. Dari penghasilannya selama memijat mereka sudah terbiasa menabung untuk masa depan anak-anaknya kelak. Dengan hasil memijat inilah mereka mampu menghidupi 2 anaknya yang masih bersekolah di SMA dan SD.

Mereka juga mengatakan bahwa dengan menekan jumlah anak dalam keluarga membuatnya lebih terorganisir dalam pencapaian kebutuhan hidup dan kesejahteraan ekonomi keluarga. Untuk kebutuhan sehari-hari seperi makan dan minum, membayar kontrakan rumah masih mencukupi dengan hasil bulanan kerjanya memijat. Akan tetapi untuk pergi main-main ke mall atau pergi bermain-main ke tempat hiburan sangatlah jarang mereka lakukan, karena mengingat biaya untuk kebutuhan sehari-hari dan biaya sekolah anaknya saja jika sudah terpenuhi merasa sangat bersyukur.

Dalam hal pengasuhan anak, Ibu Devi dan Pak Maman ini menjelaskan bahwa untuk pemenuhan kasih sayang, 
la selalu berupaya mendengarkan keluh kesah dan masalah yang dihadapi anak. Meskipun hal ini sepele, tetapi akan berdampak besar terhadap perkembangan kepribadian anak. Dengan kata lain, anak yang dibesarkan dengan penuh perhatian dan kasih sayang akan cenderung lebih menghargai orang tua, memiliki kedekatan emosional yang tinggi, dan lebih mudah untuk diberikan pengarahan oleh orang tua.

Berkaitan dengan peran orang tua, Ibu Devi dan Pak Maman selalu berusaha menjalankan perannya sebaik mungkin, agar anak merasakan kasih sayang, perlindungan, rasa nyaman dan aman sehingga merasa betah berada di rumah bersama keluarga. Meskipun dengan keadaan fisik yang terbatas, bukan menjadi halangan untuk mengajarkan kebaikan kepada anak. Misalnya, keseharian anaknya saat berada di sekolah, sepulang anaknya di sekolah atau pada malam hari biasanya Ibu Devi dan Pak Maman selalu menanyakan bagaimana cerita anakanaknya saat di sekolah. Ibu Devi dan Pak Maman selalu memberikan arahan ketika menghadapi pelajaran yang dirasa anaknya sulit untuk memahaminya seperti menyuruh anaknya untuk melakukan kerja kelompok dengan teman-temannya.

Mereka juga membiasakan anaknya untuk hidup sederhana dan disiplin dengan tujuan agar dari kecil anak sudah mulai terbentuk pribadinya, karena masa kanak-kanak adalah masa yang sangat tepat untuk mendidik sebagai modal penanaman mental dan karakter anak. Ibu Devi selalu berupaya untuk mengontrol kegiatan dan pergaulan anak agar tidak melebihi batas sehingga anak tetap mendapat perlindungan dari orang tua serta melakukan pemenuhan aspek religius terhadap anak seperti mengingatkan anaknya untuk beribadah atau shalat dengan tepat waktu.

Kendala-kendala yang dihadapi Bu Devi dan Pak Maman dalam mengasuk anaknya juga sama dengan Bu Arin dan Pak Cecep bahwa mereka mengalami kesulitan dalam hal mengontrol perkembangan belajar anak di sekolah karena keterbatasannya dalam hal penglihatan. Maka untuk mengatasinya, orang tua tunantera tidak hanya diam dan pasrah dengan keadaan. Mereka berupaya dengan kemampuannya mencari cara untuk mengatasi kendala dengan kemampuan yang dimiliki yaitu dengan memberikan arahan serta motivasi kepada anaknya untuk terus mampu mengahadapi kesulitan belajar seperti belajar kelompok dengan teman atau menyuruh anaknya untuk menanyakan kepada guru ketika ada pelajaran yang tidak dimengerti oleh anaknya, serta meminta kepada tetangga dan masyarakat di tempat tinggalnya untuk membantu anak-anaknya yang kesulitan dalam belajar.

\section{Pola Pengasuhan Anak Normal oleh Orang Tua Tuna Netra di Pati Pijat Barokah}

Berdasarkan hasil wawancara dan observasi, jenis pola asuh yang digunakan orang tua tuna netra ada dua yaitu demokratis dan otoriter. Pola asuh demokratis digunakan orang tua tunanetra sehari-hari ketika melakukan diskusi ringan dengan anak, mendengarkan keluh kesah yang dihadapi anak, serta mendengarkan keinginan atau harapan dan cita-cita anak. Pola asuh authoritative atau demokratis adalah pola asuh yang memberikan ruang dan kebebasan kepada anak untuk mengemukakan pendapat, dan melakukan apa yang 
diinginkan anak namun tetap dalam batasan dan pengawasan orang tua.

Orang tua tunanetra dalam pola asuh demokratis selalu memberikan bimbingan dan arahan dengan penuh pengertian. Hal ini sejalan dengan pendapat yang dikemukakan oleh (Baumrind, 1966) bahwa 'Pola asuh otoritatif atau demokratis adalah gaya pola asuh yang mendorong anak untuk mandiri, namun masih menempatkan batas kendali pada tindakan mereka.'

Sedangkan pola asuh kedua yang digunakan orang tua tunanetra dalam penelitian ini adalah pola asuh yang otoriter dalam hal pengawasan kepada anaknya seperti pendidikan, pergaulan dan ketika anak melakukan penyimpangan atau pelanggaran yang berat. Dalam aspek pendidikan, orang tua tunanetra sangat mengutamakannya. Orang tua berupaya agar anak mendapatkan pendidikan terbaik bahkan hingga menghantarkannya ke jenjang perguruan tinggi. Dengan keadaan fisik yang terbatas, orang tua tunanetra selalu berusaha sebaik mungkin menjalankan perannya dalam mendidik anak. Orang tua tunanetra mulai mendidik anak semenjak kecil dengan menanamkan nilai-nilai yang berlaku dalam keluarga dan masyarakat. Penanaman nilai-nilai tersebut meliputi nilai kemandirian, nilai kesopanan, nilai kedisiplinan dan nilai tanggung jawab.

Para orang tua tunanetra di Klinik Pijat Tunanetra Barokah secara keseluruhan dalam komunikasi dengan anak sehari-hari memberikan ruang dan wadah bagi anak untuk bercerita mengenai masalah-masalah yang dihadapi. Hal ini dilakukan untuk mempermudah orang tua menjalankan peran dan fungsinya. Terlebih informasi yang diterima oleh orang tua difabel kebanyakan atau bahkan satu-satunya dari pendengaran, maka dari itu orang tua tunanetra sangat membutuhkan segala informasi, masukan, dan keluh kesah yang dihadapi anak agar orang tua lebih mudah mengawasi perkembangan anak dan lebih mudah juga dalam mengarahkan dan membimbing anak.

Orangtua mempunyai peranan yang pertama dan utama bagi anak-anaknya untuk membawa anak kepada kedewasaan, maka orang tua harus memberi contoh yang baik karena anak suka mengimitasi pada orang tuanya (Mason, 1997). Kepribadian orangtua, sikap dan cara hidup mereka merupakan unsur-unsur pembinaan yang tidak langsung, yang dengan sendirinya akan masuk ke dalam pribadi anak yang sedang bertumbuh itu.

Berdasarkan hasil wawancara dan observasi, diketahui bahwa orang tua tunanetra meski dengan keadaan fisik yang terbatas, selalu berusaha sebaik mungkin menjalankan perannya dalam mendidik anak. Orang tua tunanetra mulai mendidik anak semenjak kecil dengan menanamkan nilai-nilai yang berlaku dalam keluarga dan masyarakat. Penanaman nilainilai tersebut meliputi nilai kemandirian, nilai kesopanan, nilai kedisiplinan dan nilai tanggungjawab. Sebagai orang tua, orang tua tunanetra dari masingmasing keluarga juga berupaya untuk menjadi contoh atau panutan bagi anak-anaknya. Meski dengan keadaan yang terbatas mereka berupaya sebaik mungkin dengan kemampuannya untuk dapat menjadi teladan bagi anak.

Mereka selalu berusaha melakukan apapun demi kebaikan anak. Mereka beranggapan bahwa anak selalu menjadi prioritas utama dibandingkan dengan hal-hal penting lainnya. Bahkan orang tua tunanetra sangat ingin mencukupi kebutuhan anak dan 
keluarga. Selain berperan sebagai pendidik dan panutan, orang tua tunanetra juga melaksanakan perannya sebagai pengawas, seperti yang diungkapkan oleh (Hufad, 2000) bahwa "sebagai pengawas, pada fase perubahan, sangatlah kritis bagi perkembangan anak, oleh karena itu, posisi orang tua adalah menentukan dalam mengawasi proses perubahan yang dialami anak."

Berdasarkan hasil observasi diperoleh bahwa orang tua tunanetra selalu mengawasi kegiatan anaknya. Pengawasan tersebut meliputi kegiatan mengawasi, mengkontrol dan mengarahkan anak dalam berbagai aspek yang diperhatikan orang tua seperti pendidikan, pergaulan dan sikap atau perkembangan kepribadian anak. Tujuan dari diadakannya pengawasan ini adalah untuk melindungi dan mengkontrol segala hal yang dapat berpengaruh terhadap perkembangan anak. Orang tua tunanetra selalu menyediakan waktu untuk mendengarkan masalah dan keluh kesah yang dihadapi anak. Orang tua tunanetra tidak pernah bosan hadir sebagai orang yang dapat mengerti dan memahami keadaan anak-anaknya. Selanjutnya orang tua tunanetra juga menjalankan perannya sebagai pendorong dan inspirasi bagi anak.

Setelah melakukan wawancara dan observasi diketahui bahwa dari masingmasing keluarga, orang tua tunanetra berupaya untuk selalu mendorong anak ke arah yang lebih baik dengan memberikan saran-saran, motivasi, berusaha menjadi inspirasi bagi anakanaknya. Upaya mendorong dan menjadi inspirasi dilakukan meliputi kegiatan diskusi ringan, bertukar pikiran, mengingatkan anak jika melakukan kesalahan, bercerita mengenai hikmah-hikmah dari kejadian yang telah dialami keluarga, serta memberi motivasi ketika anak mulai jenuh atau malas dalam belajar.

\section{Teori Pola Pengasuhan Anak}

Menjalankan sistem pola asuh sebenarnya juga telah menjalankan fungsi keluarga. Fungsi dalam teori fungsionalisme struktural menurut Parsons (Ritzer \& Goodman, 2010) memiliki skema yang dikenal dengan sebutan AGIL. Sistem pola asuh yang dibentuk oleh orang tua sangat berkaitan dengan skema AGIL tersebut.

Pada fase pertama yaitu Adaptation, sebuah sistem harus menanggulangi situasi eksternal yang gawat. Sistem harus menyesuaikan diri dengan lingkungan dan menyesuaikan lingkungan itu dengan kebutuhannya. Berdasarkan hasil wawancara dan observasi, orang tua tunanetra dalam penelitian ini memerankan tugasnya dengan baik. Orang tua tunanetra mengenalkan anak dengan nilai-nilai dan norma yang berlaku di lingkungan masyarakat. Mereka ingin anaknya dapat hidup baik dan rukun dengan masyarakat. Mereka juga ingin agar anak mampu beradaptasi dengan kondisi apapun yang terjadi di lingkungan.

Fase kedua yaitu Goal Attainment. Pada fase ini sebuah sistem harus mendefinisikan dan mencapai tujuan utamanya. Proses tingkah laku anak sangat dominan terlihat pada fase ini. Parsons berpandangan bahwa hal utama dalam struktur kepribadian berasal dari sistem-sistem sosial dan kebudayaan yang di internalisasi lewat sosialisasi. Anak-anak dari orang tua tunanetra setelah melalui proses adaptasi, mereka mulai menunjukkan sikap dan tingkah laku baik yang bersifat positif maupun sebaliknya. Dari pengenalan nilai-nilai yang dilakukan 
orang tua tunanetra dalam wadah sosialisasi terhadap anak, anak mulai memperlihatkan sikap dari apa yang ditangkap melalui proses sosialisasi.

Fase ketiga adalah Integration. Fase integrasi menunjukkan bahwa satu sistem harus mengatur antar-hubungan bagian-bagian yang menjadi komponennya. Sistem juga harus mengelola antar hubungan ketiga fungsi penting lainnya $(A, G, L)$. Dalam penelitian ini, orang tua tunanetra dan anak memiliki hubungan komunikasi yang baik. Mereka kesehariannya terbiasa melakukan diskusi-diskusi mengenai hal-hal yang dihadapi. Orang tua ataupun anak bebas mengemukakan pendapat dan keinginannya namun tetap dalam batas norma yang ditetapkan. Melalui proses tersebut, kerjasama antar anggota keluarga terbentuk dengan baik.

Fase yang terakhir adalah Latensi. Pada fase latensi atau pemeliharaan pola, sebuah sistem harus melengkapi, memelihara dan memperbaiki, baik motivasi individual maupun pola-pola kultural yang menciptakan dan menopang motivasi. Pada fase ini, orang tua tunanetra dan anak saling memelihara suasana keutuhan dan keharmonisan keluarga serta saling memberikan bantuan dan motivasi. Kultur dalam keluarga juga sudah terpola dengan baik.

\section{SIMPULAN}

Mayoritas tunanetra yang bekerja di Klinik Pijat Barokah berumur di atas 35 tahun ke atas dan berpendidikan SMA. Pendapatan mereka yang bekerja di Klinik Pijat Tunanetra Barokah ini mendapatkan gaji per bulanan berkisar Rp1,5-3 juta tergantung dari banyaknya pelanggan yang ingin memijat dengan mereka. Karakteristik dari tunantera yang berprofesi sebagai tukang pijat ini pada umumnya mereka belajar memijat dari pelatihan-pelatihan pijat yang mereka tekuni setelah tamat SMA seperti mengikuti pelatihan-pelatihan pijat dari Binaan Dinas Sosial.

Dalam hal pengasuhan anak orang tua tunanetra ini menerapkan pola asuh sama halnya dengan orang tua yang normal pada umumnya. Pola asuh tunanetra kepada anaknya yang sering dipakai adalah pola asuh demokratis dan otoriter, dimana mereka sering mendengarkan keluh kesah yang dihadapi anaknya saat mengalami kesulitan belajar dengan memberikan motivasi kepada anaknya. Sedangkan dalam hal pendisiplinan bagi anaknya seperti melakukan pelanggaran yang tidak diharapkan oleh orang tua tunanetra, maka orang tua tunanetra melakukan pola asuh yang otoriter dengan memberikan sanksi atau hukuman pada anaknya jika sudah melakukan pelangaran lebih dari 2 kali, dan meminta bantuan kepada tetangga dan masyarakat sekitar untuk mengontrol pergaulan anaknya agar tidak melakukan penyimpangan.

Adapun kendala-kendala yang dialami oleh orang tua tunanetra yakni mengawasi kegiatan atau pergaulan anak dan membantu anak dalam belajar atau menyelesaikan tugas-tugas sekolah, misalnya dalam mengawasi kegiatan anak dan memberikan pelajaran tambahan kepada anak.

Ada dua upaya yang dilakukan oleh orang tua tunanetra dalam mengatasi kendala pola asuh yakni. Pertama melakukan tindakan preventif (memberikan peringatan kepada anak) dan represif adalah dengan memberikan hukuman-hukuman kecil kepada anaknya seperti mengurung anaknya di kamar mandi dan tidak memberikan uang jajan saat ia melakukan kesalahan. 


\section{REKOMENDASI}

Upaya orang tua tunanetra yang kedua dilakukan dengan meminta bantuan kepada orang lain yaitu melalui konsultasi dengan orang-orang terdekat yang dapat dipercaya. Ketika anak mengalami kesulitan dalam pelajaran tertentu, orang tua tunanetra segera menanyakan kepada gurunya atau teman-temannya yang tinggal di lingkungan sekitar (Tarsidi, 2007). Disamping itu dalam hal pengawasan terhadap kegiatan anak, orang tua meminta bantuan kepada masyarakat sekitar tempat tinggalnya untuk memantau pergaulan anaknya agar tidak terjadi penyimpanganpenyimpangan.

\section{DAFTAR PUSTAKA}

Baumrind, D. (1966). Effects of Authoritative Parental Control on Child Behavior. Child Development, $37(4)$.

Carr, \& Alan. (2009). The Effectiveness of family therapy and systemic interventions for child-focused problems. Journal of Family Therapy, 31(1).

Darling, N., \& Steinberg, L. (1993). Parenting style as context: An integrative model. Psychological Bulletin, 113(3), 487-496.
Hufad, A. (2000). Peran Keluarga Inti dalam Mendidik Anak. Jurnal Pendidikan Luar Sekolah, 1(1), 6167.

Lannelli Vincent, M. D. (2004). Parenting Style. Departement of Education. Retrieved from http://www.about.com

Mason, H. (1997). Visual Impairment (access to education for children and young people). London: David Fulton Publishers.

Meyer, L. H. (2001). Multiculturalism and Severe Disabilities. Journal of the Association for Persons with Severe Handicaps, 26(3), 204-205.

Ritzer, G., \& Goodman, D. J. (2010). Teori Sosiologi Modern. Edisi Keenam. Jakarta: Kencana.

Rusch, F. R. (1990). Critical Issues in the Lives of People with Disabilities. Baltimore.: Paul H. Brookes Publishing Co.

Tarsidi, D. (2007). Peranan Hubungan Teman Sebaya dalam Perkembangan Kompetensi Sosial Anak. Penelitian. Bandung: Universitas Pendidikan Indonesia. 